\title{
Status Gizi, Asupan Energi dan Zat Gizi Makro Pasien Kanker yang Menjalani Kemoterapi di Rumkital Dr. Ramelan Surabaya
}

\author{
Nutritional Status, Energy and Macronutrient Intake of Cancer Patients \\ undergoing Chemotherapy in Dr. Ramelan Naval Hospital Surabaya
}

\author{
Annisa Rachma Firdausi Darmawan*1, Merryana Adriani ${ }^{1}$
}

\begin{abstract}
ABSTRAK
Latar Belakang: Kanker merupakan salah satu penyakit tidak menular yang ditandai oleh pertumbuhan sel yang tidak normal.Salah satu pengobatan berbasis medis yang dilakukan yaitu kemoterapi.Kemoterapi menyebabkan terjadinya penurunan nafsu makan sehingga berdampak pada kecukupan asupan, salah satunya yaitu kecukupan asupan yang meliputi energi dan zat gizi makro (energi, protein, lemak, dan karbohidrat).Tidak jarang bagi pasien kanker mengalami penurunan asupan terlebih telah menjalani kemoterapi.Dalam jangka panjang hal tersebut memiliki efek samping pada penurunan status gizi di kemudian hari.

Tujuan: Penelitian ini bertujuan untuk menganalisis hubungan antara asupan energi dan zat gizi makro dengan status gizi pasien kanker yang menjalani kemoterapi di Rumkital Dr. Ramelan Surabaya.

Metode: Desain penelitian yang digunakan adalah cross sectional. Populasi dalam penelitian ini adalah pasien kanker yang dijadwalkan akan melakukan kemoterapi pada bulan April hingga Mei 2019 dengan usia $\geq 19$ tahun. Sebanyak 75 pasien dipilih menjadi sampel dengan menggunakan teknik accidental sampling. Data yang dikumpulkan meliputi data karakteristik responden melalui wawancara, asupan makan dengan metode $2 \times 24$ hours food recall, serta status gizi berdasarkan berat badan dan tinggi badan menggunakan standar Indeks Massa Tubuh dari Kemenkes 2014.

Hasil: Responden memiliki kecukupan asupan yang meliputi energi dan zat gizi makro (lemak dan karbohidrat) dalam kategori adekuat ( $\geq 70 \%$ kebutuhan), kecuali kecukupan protein yang masih dalam kategori tidak adekuat $(<70 \%$ kebutuhan). Sementara distribusi status gizi responden sebagian besar normal (44.00\%), overweight (17.30\%), dan obesitas (16.00\%).Adapun terdapat hubungan yang signifikan antara asupan zat gizi makro dengan status gizi pasien kanker yang menjalani kemoterapi dengan signifikansi $<0.05$.

Kesimpulan: Ditemukan korelasi atau hubungan antara asupan yang meliputi energi dan zat gizi makro (protein, lemak, dan karbohidrat) dengan status gizi pasien kanker yang menjalani kemoterapi di Rumkital Dr. Ramelan Surabaya.
\end{abstract}

Kata kunci: kanker, kemoterapi, asupan energi dan zat gizi makro, status gizi

\section{ABSTRACT}

Background: Cancer is one of the non-communicable diseases characterized by abnormal cell growth. One of the medicalbased treatments of this disease is chemotherapy. Chemotherapy decreases appetite which has an impact on the adequacy of nutrients intake, one of which is the adequacy of energy and macronutrients intake. Cancer patients who have undergone chemotherapy usually experience a decrease in food intake which has side effects on decreasing nutritional status.

Objectives: This study aimed to analyze the relationship between energy and macronutrients (protein, fat, and carbohydrate) intake with the nutritional status of cancer patients undergoing chemotherapy at Rumkital Dr. Ramelan Surabaya.

Methods: The design of this research was cross sectional which population were cancer patients who were scheduled to do chemotherapy in April to May 2019 with age $\geq 19$ years old. A total of 75 patients were selected using accidental sampling technique. Data collected included respondents' characteristics through interviews, food intake with $2 \times 24$ hours food recall, and nutritional status using Body Mass Index standard from the Ministry of Health 2014.

Results: Respondents had adequate energy intake and adequate macronutrients (fat and carbohydrate) intake ( $\geq 70 \%$ needs), except protein which had inadequate intake ( $<70 \%$ needs). While the nutritional status of respondents were mostly normal (44.00\%), overweight (17.30\%), and obese (16.00\%). There was a significant correlation between macronutrients intake and the nutritional status of cancer patients undergoing chemotherapy with a significance of $<0.05$. 
Conclusions: There was a correlation between energy and macronutrients (protein, fat, and carbohydrate) intake with the nutritional status of cancer patients undergoing chemotherapy at Rumkital Dr. Ramelan Surabaya.

Keywords: cancer, chemotherapy, energy and macronutrients intake, nutritional status

\author{
*Koresponden: \\ rachmannisa18@gmail.com \\ 1,2Prodi S-1 Gizi Fakultas Kesehatan Masyarakat Universitas Airlangga, Kampus C Mulyorejo, 60115, Surabaya, Indonesia
}

\section{PENDAHULUAN}

Kanker merupakan satu dari ribuan bahkan jutaan penyakit tidak menular yang ditandai oleh pertumbuhan sel secara abnormal.Sel kanker dapat menyerang ke seluruh organ maupun jaringan yang terdapat dalam tubuh manusia.Setiap sel kanker yang menyerang organ maupun jaringan memiliki bentuk dan keganasan yang berbeda-beda, sehingga membutuhkan manajemen terapi yang spesifik. Istilah lain yang digunakan dalam mendeskripsikan kanker yaitu tumor ganas.

Kanker adalah penyebab kematian kedua di dunia dengan kisaran angka kematian mencapai 9.6 juta kasus pada 2018 lalu.Berdasarkan laporan WHO di tahun 2018, jenis kanker yang paling sering menyerang kelompok laki-laki yaitu kanker paru-paru, prostat, kolorektal, lambung, dan liver.Sementara yang sering terjadi pada kelompok perempuan yaitu kanker payudara, kolorektal, paru-paru, serviks, dan tiroid ${ }^{1}$.

Prevalensi kejadian kanker di Indonesia pada tahun 2018diketahui sebesar 1,79 per 1000 penduduk, meningkat dari tahun 2013 yang hanya mencapai 1,4 per 1000 penduduk. Provinsi dengan tingkat kejadian tertinggi adalah Provinsi DI Yogyakarta dengan prevalensi sebesar 4,86 per 1000 penduduk, disusul dengan peringkat kedua adalah Provinsi Sumatera Barat dengan prevalensi 2,47 per 1000 penduduk, dan pada peringkat ketiga adalah Provinsi Gorontalo dengan prevalensi sebesar 2,44 per 1000 penduduk $^{2}$. Sementara data yang didapatkan dari Dinas Kesehatan Kota Surabaya tahun 2015, diketahui bahwa kejadian kanker di Kota Surabaya mengalami total peningkatan sebesar $1,62 \%$ mulai dari tahun 2013 ke tahun 2015. Pada kurun waktu tersebut didapatkan data bahwa kejadian kanker tertinggi di Kota Surabaya adalah kanker payudara, disusul oleh kejadian kanker kedua tertinggi yaitu kanker serviks ${ }^{3}$.

Rumkital Dr. Ramelan merupakan salah satu rumah sakit di Kota Surabaya dengan akreditasi lulus paripurna yang menjadi rumah sakit rujukan untuk menangani berbagai masalah kesehatan, salah satunya yaitu penyakit kanker. Rumkital Dr. Ramelan juga memiliki fasilitas yang dikhususkan untuk penderita kanker, yaitu Chemotherapy Center.Berdasarkan data rekam medis di Rumkital Dr. Ramelan Surabaya, diketahui pada bulan April hingga Mei 2019 terdapat total 376 pasien kanker dan 294 pasien kanker telah menjalani kemoterapi di Chemotherapy Center ${ }^{4}$.

Salah satu jenis pengobatan yang dilakukan pada penderita kanker yaitu kemoterapi.Jenis obat yang digunakan dalam kemoterapi biasa disebut dengan golongan sitostatika. Cara kerja obat dengan golongan sitostatika yaitu untuk membunuh sel-sel kanker sampai pada bagian akar dari sel tersebut, diharapkan setelah dilakukan kemoterapi tidak terjadi metastase sel kanker ke jaringan maupun organ tubuh yang lain $^{5}$. Jalur pemberian obat anti kanker ini melalui intravena, dapat berupa infus maupun suntikan. Sementara itu kemoterapi memiliki efek samping, beberapa diantaranya yaitu mual, muntah, rambut mudah rontok, diare, dan mulut terasa pahit ${ }^{6}$. Kondisi seperti ini yang menyebabkan penurunan nafsu makan dan dapat berpengaruh pada penurunan status gizi dalam jangka panjang7.

Kemoterapi dengan status gizi pasien kanker merupakan dua hal yang saling berhubungan secara positif. Kemoterapi yang dilakukan pada pasien kanker menyebabkan terjadinya penurunan nafsu makan akibat mual dan muntah ${ }^{8}$. Hal ini disebabkan karena reseptor mual dan muntah pada hipotalamus dirangsang oleh zat antitumor yang didapatkan pada proses kemoterapi ${ }^{9}$. Namun sebaliknya kemoterapi juga akan berhasil secara optimal apabila ditunjang oleh status gizi yang baik. Status gizi yang baik (normal) menandakan bahwa asupan juga baik secara kualitas maupun kuantitas. Apabila status gizi dan asupan penderita kanker masuk ke dalam kategori yang baik, maka hal tersebut dapat menurunkan risiko penyakit penyerta lain serta dapat menurunkan gejala yang disebabkan akibat efek samping kemoterapi. Selain itu penderita juga akan merasa lebih sehat dan pemulihan akan berjalan dengan lancar ${ }^{10}$.

Pasien kanker dengan kemoterapi sangat rentan mengalami penurunan berat badan dikarenakan asupan tidak adequate. Menurut pernyataan dari Marischa (2017) sebanyak $90 \%$ pasien kanker yang telah menjalani kemoterapi akan mengalami penurunan nafsu makan diikuti dengan adanya penurunan berat badan ${ }^{7}$. Apabila tidak dilakukan intervensi dengan baik dan benar, akan membawa pasien kanker masuk ke dalam kondisi malnutrisi. Kondisi malnutrisi memberikan efek yang buruk bagi pasien, salah satunya obat yang diberikan melalui proses kemoterapi tidak dapat bekerja secara optimal11. Adapun faktor-faktor penyebab terjadinya malnutrisi pada pasien kanker yaitu kaheksia, anoreksia, serta adanya perubahan metabolisme energi dan zat gizi makro ${ }^{7}$.

Pada pasien kanker, asupan energi dan zat gizi makro (protein, lemak, dan karbohidrat) perlu diperhatikan secara spesifik ${ }^{7,11}$. Energi dan zat gizi makro (protein, lemak, dan karbohidrat) memiliki peranan penting dalam menjaga status gizi pasien agar tetap berada pada rentang normal, mengingat akan terjadi perubahan metabolisme pada pasien kanker yang 
berdampak pada penurunan status gizi ${ }^{11}$. Kebutuhan akan asupan energi dan zat gizi makro (protein, lemak, dan karbohidrat) pada pasien kanker berbeda setiap individu, kebutuhan ini dapat dipengaruhi oleh beberapa situasi dan kondisi yang terjadi di dalam tubuh pasien kanker, mulai dari tingkatan stress, tingkatan metabolisme yang terjadi dalam tubuh, serta kondisi komplikasi dengan penyakit selain kanker.

Seorang pasien kanker dikatakan cukup asupan apabila persentase kecukupan konsumsi energi dan zat gizi makro (protein, lemak, dan karbohidrat) mencapai 70\% dari kebutuhan. Berdasarkan Pedoman Nasional Pelayanan Kedokteran Kanker(PNPK)yang disusun oleh Komite Penanggulangan Kanker Nasional, angka kecukupan tersebut dapat digunakan sebagai standar kecukupan pada seluruh pasien dengan diagnosis kanker ${ }^{12}$.Namun penelitian yang telah dilakukan sebelumnya menyatakan bahwa pasien kanker belum memenuhi standar kecukupan seperti yang telah ditetapkan oleh Pedoman Nasional Pelayanan Kedokteran Kanker(PNPK). Hasil pada penelitian tersebut mengatakan bahwa kecukupan energi pada pasien kanker hanya mencapai $57,17 \%$, protein $37,68 \%$, lemak 53,94\%, dan karbohidrat 67,53\%. Angka-angka tersebut menunjukkan bahwa kecukupan asupan masih di bawah $70 \%$ dan dapat diartikan tidak adequate ${ }^{13}$

Status gizi merupakan ukuran tubuh manusia yang dapat dinilai berdasarkan asupan makanan serta memiliki pengaruh dalam penggunaan dan efektifitas zat gizi di dalam tubuh ${ }^{14}$. Salah satu pengukuran status gizi yang dapat dilakukan pada golongan usia dewasa dan lansia dapat dilihat berdasarkan indeks massa tubuh. Indeks massa tubuh dinilai berdasarkan berat badan dalam satuan kilogram dibandingkan dengan tinggi badan dalam satuan meter lalu dikuadratkan ${ }^{15}$. Pada pasien kanker, status gizi merupakan salah satu hal yang sangat penting untuk diperhatikan. Perubahan yang signifikan sangat memungkinkan terjadi pada pasien kanker, terlebih ketika pasien kanker sudah menjalani berbagai macam terapi yang ditujukan untuk menekan pertumbuhan sel kanker ${ }^{11}$. Salah satu cara untuk mengantisipasi adanya perubahan status gizi yang cukup signifikan yaitu dengan memerhatikan asupan energi dan zat gizi makro (protein, lemak, dan karbohidrat) dari makanan dan/atau minuman yang dikonsumsi seharihari pada penderita kanker. Dengan dilakukannya hal tersebut, maka status gizi pasien kanker lebih mudah untuk dikontrol dan dapat memberikan dampak positif pada terapi medis yang diterima oleh masing-masing penderita kanker ${ }^{16}$.

Dikarenakan permasalahan terkait asupan energi dan zat gizi makro yang meliputi protein, lemak, dan karbohidrat pada penderita kanker kerap kali terjadi dan memberikan efek jangka panjang pada perubahan status gizi, sehingga peneliti tertarik untuk melakukan penelitian yang terkait dengan analisis hubungan antara asupan energi dan zat gizi makro dengan status gizi penderita kanker. Penelitian dilakukan di Rumkital Dr. Ramelan Surabaya dikarenakan rumah sakit tersebut memiliki ruang perawatan khusus bagi pasien kanker. Sementara itu pasien kanker yang dijadikan sampel penelitian merupakan pasien kanker dengan usia $\geq 19$ tahun.

\section{METODE}

Penelitian ini bersifat observasional analitik.Data yang dibutuhkan dalam peneliltian ini didapatkan dengan tidak adanya perlakuan pada responden.Sementara itu penelitian ini menggunakan studi cross sectional atau potong lintang. Hal ini ditinjau dari kurun waktu yang sama saat melakukan pengambilan data pada subyek penelitian yang selanjutnya langsung dilakukan observasi atau pengamatan. Waktu pengambilan data berlangsung pada bulan April hingga Mei 2019 di Ruang Kemoterapi Rumah Sakit Angkatan Laut (Rumkital) Dr. Ramelan, di Kota Surabaya. Populasi dalam penelitian ini yaitu seluruh pasien kanker yang dijadwalkan akan melakukan kemoterapi pada bulan April hingga Mei 2019 dengan usia $\geq 19$ tahun. Jumlah populasi yang didapatkan yaitu 294 orang. Selanjutnya penentuan jumlah sampel dilakukan dengan menggunakan perhitungan dari Notoatmodjo ${ }^{17}$ sehingga sampel yang akan digunakan dalam penelitian ini sejumlah 75 orang. Penentuan sampel dalam penelitian ini menggunakan teknik accidental sampling.Sementara untuk kriteria inklusi yang ditetapkan pada responden dalam penelitian ini yaitu subyek memiliki usia $\geq 19$ tahun, tidak memiliki komplikasi dengan penyakit infeksi dan/atau degeneratif (data didapatkan melalui rekam medis), mampu mengonsumsi makanan dan minuman secara oral, serta bersedia menjadi responden dengan cara menandatangani lembar persetujuan yang telah diberikan oleh peneliti.

Data yang dikumpulkan dalam penelitian ini terdiri dari data karakteristik responden seperti usia, pendidikan terakhir yang ditempuh, jenis pekerjaan, diagnosis kanker, dan frekuensi kemoterapi yang telah dijalani. Data karakteristik responden diperoleh dari hasil wawancara oleh peneliti yang telah disesuaikan dengan kuisioner identitas responden.Selanjutnya adalah data antropometri, data yang dikumpulkan adalah berat badan (pengukuran dilakukan dengan menggunakan digital bathroom scale dengan ketelitian $0.1 \mathrm{~kg}$ ) dan tinggi badan (pengukuran dilakukan dengan menggunakan medline dengan ketelitian $0.1 \mathrm{~cm}$ untuk mengukur panjang ulna, selanjutnya dikonversikan menjadi tinggi badan). Pengukuran antropometri digunakan untuk menentukan status gizi berdasarkan Indeks Massa Tubuh (IMT) yang mengacu pada standar dari Kementerian Kesehatan dalam Peraturan Menteri Kesehatan (Permenkes) Republik Indonesia Nomer 41 tahun $2014^{18}$. Data asupan makan diperoleh dari hasil wawancara berdasarkan kuisioner $2 \times 24$ hours food recall. $2 \times 24$ hours food recall dilakukan pada dua hari yang tidak berurutan (satu hari pada weekday, dan satu hari pada weekend) untuk mengetahui jumlah asupan energi dan zat gizi makro (protein, lemak, dan karbohidrat) pada responden. Data asupan makan yang telah didapatkan akan diterjemahkan menjadi energi dan zat gizi makro (protein, lemak, dan karbohidrat) 
dengan menggunakan aplikasi Nutri-Survey. Selanjutnya jumlah energi, protein, lemak, dan karbohidrat akan dibandingkan dengan kebutuhan rata-rata pasien kanker dalam sehari, dan dikonversi dalam bentuk persentase sesuai dengan aturan Kementerian Kesehatan tahun 2017 dengan kategori cukup $\geq 70 \%$ kebutuhan dan kategori kurang $<70 \%$ kebutuhan ${ }^{12}$.

Hasil pengambilan data dalam penelitian ini diuji dengan menggunakan Uji Korelasi Spearman dengan data numerik untuk mengetahui hubungan antara asupan energi dan zat gizi makro (protein, lemak, dan karbohidrat) dengan status gizi pada pasien kanker yang menjalani kemoterapi. Sebelumnya data akan diuji normalitasnya dengan menggunakan Uji KolmogorovSmirnov. Penelitian ini telah lolos kaji etik dengan nomor 16/EC/KERS/2019 dari Komisi Etik Rumah Sakit Angkatan Laut (Rumkital) Dr. Ramelan Surabaya.

\section{HASIL DAN PEMBAHASAN}

Karakteristik responden yang diteliti dalam penelitian ini yaitu usia, jenis kelamin, pendidikan terakhir, jenis pekerjaan, diagnosis kanker, dan frekuensi kemoterapi. Distribusi karakteristik responden ditampilkan dalam tabel 1.

Berdasarkan tabel karakteristik responden, dapat diketahui bahwa terdapat tiga golongan usia yaitu remaja (17-25 tahun), dewasa (26-45 tahun), dan lansia (46->65 tahun). Dari 75 responden, 52 responden (69.30\%) berada pada golongan usia lansia. Hasil penelitian ini sejalan dengan Infodatin Kanker 2015 19 bahwa prevalensi tertinggi pasien kanker berada pada golongan usia 46-54 dengan prevalensi $3.5 \%$, usia 55-64 dengan prevalensi $3.2 \%$, usia 65-74 dengan prevalensi $3.9 \%$, dan usia 75 tahun ke atas dengan prevalensi $5.0 \%$. Berdasarkan sebaran jenis kelamin, sebagian besar responden berjenis kelamin perempuan, yaitu sebanyak 55 responden (73.30\%). Hal ini sejalan dengan penelitian yang dilakukan oleh Dewi (2017), bahwa sebagian besar penderita kanker di Indonesia berjenis kelamin perempuan $(68.8 \%)^{20}$. Berdasarkan Riset Kesehatan Dasar tahun 2018 juga dinyatakan bahwa prevalensi perempuan yang menderita kanker sebesar $2.9 \%$, sementara untuk laki-laki sebesar $0.7 \%^{2}$

Pendidikan terakhir yang ditempuh oleh responden sebagian besar adalah SMA yaitu sebanyak 29 responden (38.70\%).Sementara yang paling sedikit adalah diploma, sebanyak 1 responden (1.30\%). Dilihat dari sebaran jenis pekerjaan, sebanyak 42 responden menyatakan tidak bekerja bahkan sudah mengalami purna tugas (pensiun) (56.00\%) dan masing-masing 1 responden yang bekerja sebagai TNI dan Polisi (1.30\%). Distribusi diagnosis kanker yang paling banyak diderita oleh responden yaitu kanker payudara, dengan jumlah penderita sebanyak 29 orang (38.70\%). Hal ini ditunjang dengan data yang telah disebutkan dalam GLOBOCAN 2012, bahwa kanker yang paling banyak diderita oleh masyarakat di seluruh dunia yaitu kanker payudara untuk golongan jenis kelamin perempuan (1.67 juta kasus) dan kanker paru-paru untuk golongan jenis
Tabel 1. Karakteristik Responden

\begin{tabular}{|c|c|c|}
\hline \multirow[t]{2}{*}{ Variabel } & Jumlah & Persentase \\
\hline & $n$ & $\%$ \\
\hline \multicolumn{3}{|l|}{ Usia } \\
\hline $\begin{array}{l}\text { Remaja (17-25 } \\
\text { tahun) }\end{array}$ & 2 & 2.70 \\
\hline $\begin{array}{l}\text { Dewasa (26-45 } \\
\text { tahun) }\end{array}$ & 21 & 28.00 \\
\hline $\begin{array}{l}\text { Lansia (46->65 } \\
\text { tahun) }\end{array}$ & 52 & 69.30 \\
\hline Total & 75 & 100.00 \\
\hline \multicolumn{3}{|l|}{ Jenis Kelamin } \\
\hline Perempuan & 55 & 73.30 \\
\hline Laki-laki & 20 & 26.70 \\
\hline Total & 75 & 100.00 \\
\hline \multicolumn{3}{|l|}{ Pendidikan Terakhir } \\
\hline SD & 28 & 37.30 \\
\hline SMP & 12 & 16.00 \\
\hline SMA & 29 & 38.70 \\
\hline Diploma & 1 & 1.30 \\
\hline Sarjana & 5 & 6.70 \\
\hline Total & 75 & 100.00 \\
\hline \multicolumn{3}{|l|}{ Jenis Pekerjaan } \\
\hline Jasa & 6 & 8.00 \\
\hline Pedagang & 4 & 5.30 \\
\hline Petani & 2 & 2.70 \\
\hline PNS & 5 & 6.70 \\
\hline Polisi & 1 & 1.30 \\
\hline TNI & 1 & 1.30 \\
\hline Swasta & 9 & 12.00 \\
\hline Wiraswasta & 5 & 6.70 \\
\hline Tidak bekerja & 42 & 56.00 \\
\hline Total & 75 & 100.00 \\
\hline \multicolumn{3}{|l|}{ Diagnosis Kanker } \\
\hline Ca Colon & 23 & 30.70 \\
\hline Ca Empedu & 1 & 1.30 \\
\hline Ca Kelenjar Getah & 3 & 4.00 \\
\hline Bening & 3 & 4.00 \\
\hline Ca Kulit & 1 & 1.30 \\
\hline Ca Liver & 1 & 1.30 \\
\hline Ca Nasofaring & 2 & 2.70 \\
\hline Ca Ovarium & 1 & 1.30 \\
\hline Ca Parotis & 29 & 38.70 \\
\hline Ca Payudara & 1 & 1.30 \\
\hline Ca Rectum & 2 & 2.70 \\
\hline Ca Serviks & 4 & 5.30 \\
\hline Ca Sigmoid & 3 & 4.00 \\
\hline Ca Tulang & 1 & 1.30 \\
\hline \multicolumn{3}{|l|}{ Ca Vagina } \\
\hline Total & 75 & 100.00 \\
\hline \multicolumn{3}{|l|}{ Frekuensi } \\
\hline Kemoterapi & 20 & 26.70 \\
\hline 2 & 19 & 25.30 \\
\hline 3 & 36 & 48.00 \\
\hline \multicolumn{3}{|l|}{4} \\
\hline Total & 75 & 100.00 \\
\hline
\end{tabular}

kelamin laki-laki (1.82 juta kasus) ${ }^{21}$. Di Indonesia, kanker payudara memiliki peringkat kedua tertinggi dengan prevalensi $0.5 \%$ dan angka kejadian di seluruh provinsi 
sebanyak 61682 kasus pada tahun $2013^{19}$. Selanjutnya sebaran berdasarkan frekuensi kemoterapi yang telah dilakukan oleh responden, yaitu sebanyak 36 responden telah menempuh kemoterapi sebanyak 4 kali (48.00\%), 20 responden telah menempuh kemoterapi sebanyak 2 kali $(26.70 \%)$, dan 19 responden telah menempuh kemoterapi sebanyak 3 kali $(25.30 \%)$.

Tabel 2. Rata-rata Tingkat Konsumsi Energi dan Zat Gizi Makro

\begin{tabular}{lcc}
\multicolumn{1}{c}{ Makro } & \\
& $\begin{array}{c}\text { Rata-Rata Tingkat } \\
\text { Konsumsi }\end{array}$ & $\begin{array}{c}\text { Persentase } \\
\text { (\%) }\end{array}$ \\
\hline Energi (kkal) & $1307.39 \pm 548.58$ & 78.52 \\
Protein (gram) & $45.65 \pm 22.49$ & 54.71 \\
Lemak (gram) & $53.20 \pm 27.50$ & 83.79 \\
Karbohidrat & $214.44 \pm 120.30$ & 115.77 \\
(gram) & & \\
\hline
\end{tabular}

Tabel 2 menunjukkan rata-rata konsumsi energi dan zat gizi makro (energi, protein, lemak, dan karbohidrat) dari keseluruhan 75 pasien kanker yang menjadi responden dalam penelitian ini. Dari 75 responden, didapatkan rata-rata konsumsi energi $1307.39 \pm 548.58 \mathrm{kkal}$, protein $45.65 \pm 22.49$ gram, lemak $53.20 \pm 27.50$ gram, dan karbohidrat $214.44 \pm$ 120.30 gram.

Selanjutnya pada tabel 2 juga menunjukkan ratarata persentase tingkat asupan dari total 75 responden. Sebelum dilakukan perhitungan rata-rata, tingkat asupan energi dan zat gizi makro dari masing-masing responden dibandingkan dengan kebutuhan energi dan zat gizi makro untuk pasien kanker. Adapun kebutuhan energi untuk pasien kanker yaitu $30 \mathrm{kkal} / \mathrm{kg} \mathrm{BB} / \mathrm{hari}$, protein sebesar $1.5 \mathrm{gram} / \mathrm{kg} \mathrm{BB} /$ hari atau setara dengan $20 \%$ dari kebutuhan kalori, lemak sebesar $35 \%$ dari kebutuhan kalori, serta karbohidrat sebesar $45 \%$ dari total kebutuhan kalori22. Sehingga didapatkan rata-rata persentase tingkat asupan dari 75 responden yaitu 78.52\% untuk energi, 54.71\% untuk protein, 83.79 untuk lemak, dan $115.77 \%$ untuk karbohidrat.Dibandingkan dengan penelitian yang telah dilakukan sebelumnya, bahwa penelitian ini memiliki hasil yang tidak sejalan. Hasil pada penelitian tersebut mengatakan bahwa persentase tingkat asupan energi pada pasien kanker hanya mencapai $57,17 \%$, protein $37,68 \%$, lemak $53,94 \%$, dan karbohidrat $67,53 \% .{ }^{13}$. Perbedaan yang cukup signifikan dikarenakan pada penelitian ini responden masih berada pada siklus awal kemoterapi dan baru saja menjalani kemoterapi sebanyak 2 hingga 4 kali, sementara pada penelitian sebelumnya sebaran frekuensi kemoterapi lebih beragam, tidak hanya pada siklus awal kemoterapi saja. Hal ini menyebabkan adanya perbedaan nafsu makan yang berdampak pada perbedaan asupan energi dan zat gizi makro.

Sementara itu tabel 3 menunjukkan distribusi kecukupan energi dan zat gizi makro pada responden. Kecukupan energi dan zat gizi makro pada responden dikatakan adequate apabila memenuhi $\geq 70 \%$ dari kebutuhan dan dikatakan inadequate apabila hanya memenuhi $>70 \%$ dari kebutuhan ${ }^{12}$. Hasil penelitian ini menunjukkan bahwa sebagian besar asupan energi dan zat gizi makro (lemak dan karbohidrat) pada responden termasuk dalam kategori adequate. Hanya dalam konsumsi protein saja sebagian besar responden masuk dalam kategori inadequate, yaitu sebanyak 58 responden (77.30\%).

Menurut tatalaksana nutrisi pasien kanker yang dituliskan dalam ESPEN Guideline, dikatakan bahwa asupan yang meliputi energi dan zat gizi makro (energi, protein, lemak, dan karbohidrat) hanya terpenuhi $<60 \%$ dari total kebutuhan pasien kanker dalam sehari ${ }^{23}$. Hasil penelitian ini tidak sesuai dengan yang dituliskan dalam ESPEN Guideline.Berdasarkan hasil penelitian ini asupan energi, lemak, dan karbohidrat termasuk dalam kategori adequate atau cukup, hanya protein saja yang tergolong dalam kategori inadequate atau tidak cukup.

Tabel 3. Distribusi Asupan Zat Gizi Makro

\begin{tabular}{|c|c|c|}
\hline Asupan Zat Gizi Makro & $\mathbf{n}$ & $\%$ \\
\hline \multicolumn{3}{|l|}{ Kecukupan Asupan } \\
\hline \multicolumn{3}{|l|}{ Energi } \\
\hline $\begin{array}{l}\text { Adequate ( } \geq 70 \% \text { Kebutuhan) } \\
\text { Inadequate }(<70 \%\end{array}$ & 44 & 58.70 \\
\hline Kebutuhan) & 31 & 41.30 \\
\hline Total & 75 & 100.00 \\
\hline \multicolumn{3}{|l|}{ Protein } \\
\hline Adequate ( $\geq 70 \%$ Kebutuhan) & 17 & 22.70 \\
\hline \multicolumn{3}{|l|}{ Inadequate $(<70 \%$} \\
\hline Kebutuhan) & 58 & 77.30 \\
\hline Total & 75 & 100.00 \\
\hline \multicolumn{3}{|l|}{ Lemak } \\
\hline $\begin{array}{l}\text { Adequate }(\geq 70 \% \text { Kebutuhan }) \\
\text { Inadequate }(<70 \%\end{array}$ & 43 & 57.30 \\
\hline Kebutuhan) & 32 & 42.70 \\
\hline Total & 75 & 100.00 \\
\hline \multicolumn{3}{|l|}{ Karbohidrat } \\
\hline \multicolumn{2}{|l|}{ Inadequate $(<70 \%$} & 77.30 \\
\hline Kebutuhan) & 17 & 22.70 \\
\hline Total & 75 & 100.00 \\
\hline
\end{tabular}

Perbedaan hasil dari penelitian ini dengan ESPEN Guideline dapat dipengaruhi oleh beberapa hal, salah satunya adalah frekuensi kemoterapi yang telah dilakukan oleh responden. Responden dalam penelitian ini telah menjalani kemoterapi sebanyak 2 hingga 4 kali saja, hal ini dapat diartikan bahwa pasien kanker tersebut masih dalam tahap awal kemoterapi (siklus pertama). Dapat diketahui bahwa dalam satu siklus kemoterapi akan dilakukan sebanyak enam kali pemberian obat kemoterapi, baik melalui oral maupun intravena ${ }^{24}$. Frekuensi pemberian kemoterapi pada pasien kanker juga berbeda-beda, tergantung kebutuhan dari masing-masing pasien kanker. Beberapa contoh dari pemberian kemoterapi diperuntukkan untuk memerkecil ukuran tumor yang dapat menyebabkan rasa sakit pada pasien kanker, mencegah, memerlambat, dan menghancurkan sel kanker yang telah menyebar ke bagian tubuh yang lain, serta mencegah munculnya kembali sel kanker di dalam tubuh (pembersihan sel atau 
jaringan pasca operasi) ${ }^{25}$. Data yang didapatkan dari penelitian yang dilakukan di Ruang Kemoterapi Rumkital Dr. Ramelan Kota Surabaya ini menunjukkan bahwa responden masih termasuk dalam tahap awal kemoterapi (masih berada pada siklus pertama kemoterapi) sehingga asupan energi dan zat gizi makro seperti lemak dan karbohirat masih dalam kategori adequate atau cukup dikarenakan nafsu makan responden yang masih stabil dan belum ada pengaruh yang signifikan dari proses kemoterapi.

Mengenai asupan protein yang inadequate atau tidak cukup, dapat disebabkan karena kesalahan dalam pemilihan bahan makanan. Ketika dilakukan wawancara pada responden, 75 responden (100\%) mengatakan bahwa dalam keseharian mereka, lauk pauk yang mereka konsumsi berasal dari sumber protein nabati, seperti tahu dan tempe. Dapat diketahui bahwa kandungan asam amino essensial dalam protein nabati jauh di bawah protein hewani sehingga asupan protein dalam sehari belum dapat memenuhi standar kecukupan yang sudah ditetapkan khusus bagi penderitakanker 26,27 . Alasan lain yang dipaparkan responden terkait dengan konsumsi protein yang kurang, karena $83 \%$ responden masih percaya bahwa konsumsi protein hewani seperti ikan, telur, ayam, dan daging merupakan hal yang taboo serta menyebabkan luka pasca operasi maupun inflamasi jaringan akibat penyakit yang mereka derita sulit untuk sembuh serta pulih. Beberapa dari responden dalam penelitian ini masih dalam fase penyembuhan pasca operasi sehingga luka bekas operasi pada responden tersebut masih belum sembuh betul, terutama pasien dengan diagnosis kanker payudara yang baru saja melakukan operasi pengangkatan jaringan payudara.Hal ini sejalan dengan penelitian yang dilakukan oleh Elisa (2014) dan Widyasari (2013) dalam Madiyanti dkk (2016) pada ibu pasca melahirkan dengan operasi SC, dikarenakan asupan protein yang kurang menyebabkan luka pasca operasi sembuh dalam jangka waktu yang cukup lama. Pada penelitian tersebut juga dikatakan bahwa masyarakat Indonesia masih banyak yang menganut kepercayaan terkait food taboo atau pantangan makanan ${ }^{28}$.

Banyak hal yang menyebabkan terjadinya penurunan asupan energi dan zat gizi makro (energi, protein, lemak, dan karbohidrat) pada penderita kanker, beberapa diantaranya karena adanya peningkatan katabolisme, terapi medis yang dapat menurunkan nafsu makan seperti efek anastesi akibat dilakukannya operasi atau pembedahan, kemoterapi, dan juga radiasi serta kurangnya motivasi dan dukungan baik dari dalam diri sendiri maupun lingkungan sekitar ${ }^{16}$. Apabila ditinjau secara spesifik dari efek kemoterapi, kemoterapi dapat memberikan beberapa efek pada pasien kanker, yaitu mual, muntah, sariawan berlebih pada rongga mulut, gangguan pada saluran pencernaan bagian atas maupun bawah yang pada akhirnya akan berujung pada terjadinya penurunan nafsu makan ${ }^{29}$. Berdasarkan penelitian ini terdapat 46 dari 75 responden yang mengalami penurunan nafsu makan.Ada atau tidaknya penurunan nafsu makan pada responden ditinjau berdasarkan hasil dari wawancara dengan metode In
Depth Interview. Penurunan nafsu makan pada 46 responden terjadi pada hari pertama dan kedua pasca kemoterapi, pada hari ketiga nafsu makan pada 46 responden tersebut akan kembali normal. Dikarenakan penurunan nafsu makan hanya terjadi kurang lebih dua hari saja pasca kemoterapi, sehingga responden belum mengalami penurunan status gizi secara signifikan.

Tabel 4 menunjukkan distribusi status gizi pada responden.Sebagian besar responden memiliki status gizi normal (44.00\%), diikuti dengan responden yang memiliki status gizi overweight sebanyak 13 orang (17.30\%), dan responden dengan kategori obesitas sejumlah 12 responden (16.00\%). Hasil penelitian ini sejalan dengan penelitian yang dilakukan oleh Putri (2018) bahwa sebagian besar responden memiliki status gizi normal $(42 \%)^{13}$. Terdapat kesamaan juga dengan penelitian yang dilakukan oleh Vries, et al. (2017) bahwa sebagian besar responden memiliki rata-rata status gizi pada angka $25.2 \mathrm{~kg} / \mathrm{m}^{2}$, yang termasuk dalam kategori status gizi overweight ${ }^{30}$. Penelitian yang dilakukan oleh Damayanti, et al. (2017) mendukung hasil yang didapatkan dalam penelitian ini. Penelitian tersebut menunjukkan bahwa sebagian besar responden memiliki status gizi normal $(81.08 \%)^{31}$. Hasil penelitian yang dilakukan oleh Hardiano, et al. (2015) menunjukkan bahwa $49 \%$ pasien kanker yang menjalani kemoterapi memiliki status gizi normal ${ }^{32}$. Ada sedikit perbedaan dari penelitian ini dengan penelitian lain yang memiliki hasil status gizi sejalan, pada penelitian ini responden merupakan seluruh pasien yang memiliki diagnosis kanker, dengan diagnosis paling banyak yaitu kanker payudara. Sementara hasil penelitian yang digunakan sebagai pembanding, keseluruhan responden memiliki diagnosis kanker payudara. Namun dari kelompok umur, seluruh penelitian memiliki kesamaan, yaitu secara keseluruhan responden memiliki umur $>18$ tahun.

Tabel 4. Distribusi Status Gizi

\begin{tabular}{lcc}
\hline Status Gizi & $\mathbf{n}$ & $\mathbf{\%}$ \\
\hline Sangat Kurus $(<17.00)$ & 11 & 14.70 \\
Kurus $(17-<18.5)$ & 6 & 8.00 \\
Normal $(18.5-25.0)$ & 33 & 44.00 \\
Overweight $(>25.0-27.0)$ & 13 & 17.30 \\
Obesitas $(>27.0)$ & 12 & 16.00 \\
\hline Total & $\mathbf{7 5}$ & $\mathbf{1 0 0 . 0 0}$
\end{tabular}
menyebabkan seseorang mengalami penurunan berat badan, sehingga indeks massa tubuh juga ikut menurun. $\mathrm{Hal}$ ini disebabkan karena terjadi penurunan jaringan lemak dan massa otot rangka ${ }^{33}$. Dikutip dari artikel yang ditulis oleh Marischa, et al. (2017) bahwa terjadi perubahan metabolisme secara spesifik pada pasien kanker.Baik itu metabolism protein, lemak, maupun karbohidrat. Perubahan metabolisme yang terjadi pada pasien kanker mengarah pada kondisi hipermetabolisme ${ }^{7}$. Namun pada hasil penelitian kali ini, sebagian besar responden memiliki status gizi normal dan lebih (overweight dan obesitas). Hal ini dapat terjadi karena beberapa hal, hal pertama didasarkan pada hasil 
wawancara dengan responden. Sebagian besar responden memiliki nafsu makan yang cukup baik, sehingga persentase kecukupan yang meliputi asupan energi dan zat gizi makro (energi, protein, lemak, dan karbohidrat) berada pada kategori cukup $(\geq 70 \%$ kebutuhan rata-rata pasien kanker). Kedua responden pada penelitian kali ini berada pada kondisi stadium awal dengan frekuensi kemoterapi tidak lebih dari satu siklus (responden baru mengikuti kemoterapi sebanyak 2, 3, atau 4 kali), sehingga belum terjadi penurunan status gizi yang signifikan, sesuai dengan yang dituliskan oleh Desen dalam Buku Ajar Onkologi Klinis (Edisi 2) ${ }^{24}$. Selanjutnya status gizi pada penelitian ini juga dapat dipengaruhi oleh efek samping kemoterapi terkait nafsu makan. Dikatakan oleh Putri (2018) bahwa efek samping kemoterapi hanya berlangsung 2 hari hingga 1 minggu setelah dilakukan kemoterapi, selanjutnya nafsu makan pada responden akan kembali seperti semula ${ }^{13}$. Namun dikarenakan hasil wawancara pada penelitian ini didapatkan sebagian besar responden tidak mengalami penurunan nafsu makan sekalipun setelah dilakukan kemoterapi, sehingga tidak menutup kemungkinan asupan akan terus masuk ke dalam tubuh, bahkan makanan maupun minuman yang dikonsumsi melebihi standar kebutuhan pasien kanker pada umumnya.

Uji hubungan yang dilakukan menggunakan aplikasi SPSS versi 16 .Untuk melihat ada atau tidaknya hubungan antara asupan energi dan zat gizi makro dengan status gizi pasien kanker yang menjalani kemoterapi digunakan uji korelasi Spearman.

Tabel 5. Hubungan Antara Asupan Energi dan Zat Gizi Makro dengan Status Gizi

\begin{tabular}{lcc}
\hline \multicolumn{2}{c}{$\begin{array}{c}\text { Asupan Energi dan Zat Gizi } \\
\text { Makro }\end{array}$} & \multicolumn{2}{c}{ Status Gizi } \\
\cline { 2 - 3 } & p-value & $\mathbf{r}$ \\
\hline Energi & 0.024 & 0.260 \\
Protein & 0.035 & 0.243 \\
Lemak & 0.047 & 0.230 \\
Karbohidrat & 0.004 & 0.330 \\
\hline
\end{tabular}

Tabel 5 menunjukkan bahwa nilai signifikansi atau p-value hubungan antara asupan energi dan zat gizi makro dengan status gizi pasien kanker yang menjalani kemoterapi adalah $<0.05$. Hasil tersebut merupakan bukti bahwa terdapat korelasi atau hubungan antara asupan pada tingkat energi dengan status gizi $(p=0.024)$, asupan pada tingkat protein dengan status gizi $(p=0.035)$, asupan pada tingkat lemak dengan status gizi $(p=0.047)$, dan asupan pada tingkat karbohidrat dengan status gizi $(p=0.004)$.

Hasil uji korelasi atau hubungan antara asupan energi dengan status gizi dapat dikatakan memiliki hasil yang sama dengan penelitian yang dilakukan oleh Sofiani dan Rahmawaty (2018). Namun tidak memiliki kesamaan apabila dilihat berdasarkan hasil uji korelasi atau hubungan antara asupan protein dan status gizi 34 . Hubungan antara asupan energi dikatakan memiliki korelasi atau hubungan dengan status gizi, dapat dilihat dalam penelitian ini bahwa asupan energi berada di atas angka $70 \%$ yang berarti masuk dalam kategori cukup, sementara itu untuk status gizi rata-rata responden dalam penelitian ini termasuk dalam golongan status gizi normal, bahkan beberapa responden memiliki status gizi lebih. Hal tersebut dapat diartikan bahwa semakin baik persentase asupan energi, maka status gizi pasien kanker berada pada angka normal atau di atas normal.Hal ini juga memiliki kesamaan dengan uji korelasi atau hubungan antara lemak dan karbohidrat dengan status gizi dalam penelitian ini.

Berbeda halnya dengan asupan protein.Dalam penelitian ini distribusi kecukupan protein pada responden masih banyak yang termasuk dalam kategori tidak adekuat, namun berdasarkan hasil uji korelasi Spearman, terdapat hubungan yang signifikan antara asupan protein dengan status gizi responden

Protein merupakan satu komponen penting yang diperlukan dalam tubuh manusia, salah satunya karena fungsi protein yang dapat memerbaiki jaringan-jaringan yang rusak di dalam tubuh.Berdasarkan fungsi tersebut konsumsi protein sangat diperlukan terutama bagi penderita kanker yang memerlukan perbaikan sel dan jaringan yang rusak.Protein didapatkan dari hewani maupun nabati.

Konsumsi protein yang cukup dapat memiliki pengaruh pada status gizi seseorang.Semakin baik dan beragam konsumsi makanan sumber protein, maka dalam jangka panjang akan memberikan efek yaitu adanya peningkatan pada status gizi.Pernyataan tersebut sejalan dengan penelitian yang dilakukan oleh Situmorang., et al (2014) dan Setiani (2012). Hasil dari penelitian tersebut menyatakan bahwa semakin baik asupan protein, maka akan terjadi peningkatan pada status gizi secara signifikan ${ }^{35,36}$.

Walaupun dalam penelitian ini masih banyak responden yang tidak adekuat dalam konsumsi protein, namun asupan protein tetap memiliki hubungan yang bermakna dengan status gizi masing-masing responden. Hal ini bisa saja terjadi, karena pada penelitian ini penentuan status gizi menggunakan standar indeks massa tubuh yang dinilai berdasarkan berat badan dibandingkan dengan tinggi badan dikuadratkan. Faktor yang dapat meningkatkan berat badan seseorang yaitu tingginya angka konsumsi karbohidrat dan lemak ${ }^{37}$. Apabila konsumsi karbohidrat dan lemak masuk dalam kategori berlebih, maka akan terjadi akumulasi penumpukan lemak di dalam tubuh ${ }^{38,39}$. Ketika angka konsumsi karbohidrat dan lemak tinggi, secara langsung kecukupan akan asupan lemak dan karbohidrat juga turut meningkat. Asupan lemak dan karbohidrat merupakan 2 dari 5 faktor yang berpengaruh secara signifikan pada status gizi, terutama pada golongan usia lansia ${ }^{40}$. Sehingga pada akhirnya apabila tingkat konsumsi lemak dan karbohidrat berada pada kategori cukup bahkan berlebih, akan diikuti dengan peningkatan status gizi yang berada pada kategori gizi normal atau bahkan lebih.

\section{KESIMPULAN}

Berdasarkan hasil dari penelitian ini dapat disimpulkan bahwa kecukupan yang meliputi asupan 
energi dan zat gizi makro (lemak dan karbohidrat) termasuk dalam kategori adequate dengan persentase $\geq 70 \%$ dari kebutuhan. Ada hubungan yang signifikan antara asupan energi dan zat gizi makro dengan status gizi pasien kanker yang menjalani kemoterapi. Hal ini menunjukkan bahwa semakin baik asupan energi dan zat gizi makro, maka status gizi juga akan semakin baik (ke arah rentang normal).

\section{ACKNOWLEDGEMENT}

Ucapan terima kasih dan pengharagaan sedalamdalamnya disampaikan kepada keseluruhan dosen program studi Ilmu Gizi Universitas Airlangga Surabaya yang telah membantu dan membimbing penulis dalam penulisan artikel ini, pihak Rumah Sakit Angkatan Laut (Rumkital) Dr. Ramelan Surabaya yang memberikan arahan serta bimbingan dalam proses pengambilan data responden untuk penulisan artikel ini, serta keluarga dan teman-teman yang telah berbesar hati untuk memberikan dukungan mereka dalam penyelesaian artikel ini. Pada penelitian selanjutnya dapat disarankan untuk menambahkan karakteristik demografi responden terkait dengan stadium kanker yang dimiliki, sehingga dapat digunakan sebagai data penunjang dan dimasukkan pada bagian pembahasan.

\section{REFERENSI}

1. WHO. Cancer Report 2018. (2018).

2. Kesehatan, K. HASIL UTAMA RISKESDAS 2018. (2018).

3. Dinas Kesehatan Pemerintah Kota Surabaya. Profil Kesehatan Tahun 2015. (2015).

4. Rumkital Dr. Ramelan. Rekam Medis Pasien. (2019).

5. Halimatussakdiah \& Junardi. Faktor Risiko Kepatuhan Kemoterapi pada Pasien Kanker Payudara. J. Kesehat.8, 415-424 (2017).

6. Suyanto \& Arumdari, P. Dukungan Keluarga pada Pasien Kanker yang Menjalani Kemoterapi. in Prosiding Unissula Nursing Conference 90-95 (Universitas Islam Sultan Agung Semarang, 2018).

7. Marischa, S., Anggraini, D. I. \& Putri, G. T. Malnutrisi pada Pasien Kanker. Medula7, 107111 (2017).

8. Habsari, A., Pradigdo, S. F. \& Aruben, R. Hubungan beberapa faktor gizi dan kemoterapi dengan status gizi penderita kanker. J. Kesehat. Masy.5, 593-599 (2017).

9. Prawirohardjo, S., Andrijono, Saifuddin, A. B. \& Aziz, F. Buku Acuan Nasional Onkologi Ginekologi. (2006).

10. Caesandri, S. D. P. \& Adiningsih, S. Peranan Dukungan Pendamping Dan Kebiasaan Makan Pasien Kanker Selama Menjalani Terapi. Media Gizi Indones.10, 157-165 (2015).

11. Kurniasari, F. N., Harti, L. B., Ariestiningsih, A. D., Wardhani, S. O. \& Nugroho, S. Buku Ajar: Gizi dan Kanker. (UB Press, 2017).
12. Komite Penanggulangan Kanker Nasional. Pedoman Nasional Pelayanan Kedokteran Kanker Payudara. (2017).

13. Putri, S. Hubungan Efek Samping Kemoterapi Terkait Nafsu Makan dan Kecukupan Zat Gizi Makro dengan Status Gizi Pasien Kanker Payudara (Studi Kasus di Rumkital Dr. Ramelan Surabaya). (Universitas Airlangga, 2018).

14. Almatsier, S. Prinsip Dasar Ilmu Gizi. (Gramedia Pustaka Utama, 2005).

15. Adriani, M. \& Wirjatmadi, B. Peranan Gizi dalam Siklus Kehidupan. (Prenadamedia Group, 2016).

16. Hardinsyah \& Supariasa, I. D. N. Ilmu Gizi Teori dan Aplikasi. (Penerbit Buku Kedokteran EGC, 2016).

17. Notoatmodjo, S. Metodologi Penelitian Kesehatan. (Rineka Cipta, 2015).

18. Kementerian Kesehatan Republik Indonesia. Peraturan Menteri Kesehatan Republik Indonesia Nomor 41 Tahun 2014 Tentang Pedoman Gizi Seimbang. (2014).

19. Pusat Data dan Informasi Kementerian Kesehatan Republik Indonesia. Infodatin Kanker. Pusat Data dan Informasi Kemenkes RI (2015).

20. Dewi, M. Sebaran Kanker di Indonesia, Riset Kesehatan Dasar 2007. Indones. J. Cancer11, 1-8 (2017).

21. Ferlay, J. et al. Cancer Incidence and Mortality Worldwide: Sources, Methods, and Major Patterns in GLOBOCAN 2012. Int. J. Cancer136, E359-E386 (2015).

22. Mahan, L. K. \& Raymond, J. L. Krause's Food and The Nutrition Care Process. (Elsevier Sauders, 2012).

23. Arends, J. et al. ESPEN Guidelines on Nutrition in Cancer Patients. Clin. Nutr.36, 11-48 (2017).

24. Desen, W. \& Japaries, W. Buku Ajar Onkologi Klinis (Edisi 2). (Balai Penerbit FKUI, 2011).

25. American Cancer Society. Cancer Facts and Figures 2017. (2017).

26. Muchtadi, D. Teknik Evaluasi Nilai Gizi Protein. (Alfabeta, 2010).

27. Sari, D. K., Marliyati, S. A., Kustiyah, L., Khomsan, A. \& Gantohe, T. M. Bioavailabilitas Fortifikan, Daya Cerna Protein, serta Kontribusi Gizi Biskuit yang Dltambah Tepung Ikan Gabus (Ophiocephalus striatus) dan Difortifikasi Seng dan Besi. Agritech34, 359-364 (2014).

28. Madiyani, D. A., Anggraeni, S. \& Melinda, A. Hubungan Asupan Protein dengan Penyembuhan Luka pada Pasien Post Op Sectio Caesarea (SC) di Rumah Sakit Umum Daerah Pringsewu Lampung Tahun 2016. J. Asuhan Ibu dan Anak3, 1-9 (2018).

29. Dewi, N. N. A. \& Aryawan, I. M. D. Frekuensi Kemoterapi dapat Menurunkan Asupan Zat Gizi dan Status Gizi pada Pasien Kanker Payudara di Ruang Perawatan Kelas III RSUP Sanglah Denpasar. Skala Husada14, 1-14 (2017).

30. de Vries, Y. C. et al. Differences in Dietary Intake During Chemotherapy in Breast Cancer Patients 
Compared to Women Without Cancer. Support Care Cancer25, 2581-2591 (2017).

31. Damayanti, A. Y., Indarto, D., Wasita, B. \& Ardyanto, T. D. Indeks Massa Tubuh, Asupan Vitamin D, dan Serum 25-Hydroxyvitamin D pada Pasien Kanker Payudara. J. Gizi Klin. Indones.14, 56-63 (2017).

32. Hardiano, R., Huda, N. \& Jumaini. Gambaran Indeks Massa Tubuh pada Pasien Kanker yang Menjalani Kemoterapi. JOM2, 1381-1388 (2015).

33. Siregar, Y. S., Widyaningsih, W. \& Syahruddin, E. Indeks Massa Tubuh, Persentase Otot Rangka, dan Albumin pada Pasien Kanker Paru Karsinoma Bukan Sel Kecil Sebelum dan Setelah Kemoterapi. J. Respir Indo36, 73-82 (2016).

34. Sofiani, E. G. \& Rahmawaty, S. Tingkat Pengetahuan Gizi, Asupan Energi-Protein, dan Status Gizi Pasien Kanker Nasofaring yang Mendapatkan Kemoterapi. Darussalam Nutr. J.2, 14-20 (2018).

35. Situmorang, A., Sudaryanti, E. \& Siregar, M. A. Hubungan Karakteristik, Gaya Hidup, dan Asupan
Gizi dengan Status Gizi pada Lansia di Wilayah Kerja Puskesmas Aek Habil Kota Sibolga. Gizi, Kesehat. Reproduksi, dan Epidemiol.1, 1-8 (2014).

36. Setiani, W. D. Hubungan antara Riwayat Penyakit, Asupan Protein, dan Faktor-Faktor Lain dengan Status Gizi Peserta Posyandu Lansia di Kecamatan Grogol Petamburan Jakarta Barat Tahun 2011. (Universitas Indonesia, 2012).

37. Sudikno, Syarief, H., Meti Dwiriani, C. \& Riyadi, H. Faktor Risiko Overweight dan Obese pada Orang Dewasa di Indonesia. J. Indones. Nutr. Assoc.38, 91-104 (2015).

38. Lanham-New, S. A., Macdonald, I. A. \& Roche, H. M. Metabolisme Zat Gizi. (Penerbit Buku Kedokteran EGC, 2015).

39. Murray, R. K. et al.Biokimia Harper (Edisi 29). (Penerbit Buku Kedokteran EGC, 2014).

40. Rohmawati, N., Asdie, A. H. \& Susetyowati, S. Tingkat Kecemasan, Asupan Makan, dan Status Gizi pada Lansia di Kota Yogyakarta. J. Gizi Klin. Indones.12, 62-71 (2015). 